\title{
CORRIGENDUM
}

\section{Predicting the incidence of hand, foot and mouth disease in Sichuan province, China using the ARIMA model - CORRIGENDUM}

L. LIU, R. S. LUAN, F. YIN, X. P. ZHU AND Q. LÜ

doi: http://dx.doi.org/10.1017/S0950268815001144 Published online: 1 June 2015

In the above article [1] the corresponding author details in the note on page 1 are incorrect. The correct details are given below. The authors apologize for this error.

Author for correspondence: Mr R. S. Luan, West China School of Public Health, Sichuan University, No. 16 Third Section of People South Road, Chengdu, Sichuan, People's Republic of China, 610041.

(Email: luan_rs@scu.edu.cn)

\section{REFERENCE}

1. Liu L, Luan RS, Yin F, Zhu XP, Lü Q. Predicting the incidence of hand, foot and mouth disease in Sichuan province, China using the ARIMA model. Epidemiology and Infection. doi:10.1017/S0950268815001144. Published online: 1 June 2015. 